\title{
Unionists after Unionism
}

\section{Colin Coulter}

To cite this article: Colin Coulter (2001) Unionists after Unionism, Peace Review, 13:1, 75-80, DOI: $10.1080 / 10402650120038170$

To link to this article: http://dx.doi.org/10.1080/10402650120038170

\section{曲 Published online: 19 Aug 2010.}

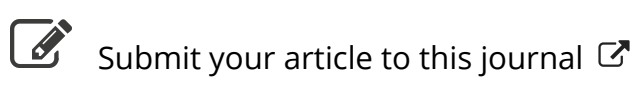

Џ Article views: 24

Q View related articles $\sqsubset$ 


\section{Unionists after Unionism}

\section{Colin Coulter}

Over the last 30 years, the conflict that has overtaken Northern Ireland has often seemed like it would never cease. People living in the region have routinely despaired at the prospects of a lasting peace. Academics and other political commentators have been conspicuous among the despondent. In the last decade, however, the perennial political gloom that shrouds Northern Ireland has apparently begun to lift. The political events the region has lately experienced suggests that Unionists and Nationalists may have begun resolving their substantial differences through means other than violence.

At the heart of this fragile peace process lies a deal struck in the spring of 1998 between representatives of most shades of Northern Irish political opinion. The Belfast Agreement addresses the complex and troubled relationships that underlie the "Northern Ireland problem." Among the most important is the relationship between people living on either side of the Irish border. The Belfast Agreement clearly envisages a future of closer ties between Northern Ireland and the Irish Republic. Under the Agreement, various bodies have been established to promote cooperation between the Belfast and Dublin parliaments on matters of mutual concern. The North-South dimension acknowledges the feelings of "Irishness" that prevail among northern Nationalists. The various cross-border bodies produced by the Belfast Agreement also represent, however, an attempt to engage the Unionist community in certain forms of political and cultural dialogue.

$\mathrm{T}$ he architects of the political settlement proposed for Northern Ireland seem to assume that a lasting peace demands important changes in the way Unionists relate to the rest of the island. The Agreement envisages the Unionist community developing closer ties not only with Nationalists living in Northern Ireland but also with those living on the other side of the Irish border. It is anticipated, in other words, that Unionists will in time take their place in a political and cultural community that encompasses the entire island.

The 1998 political deal makes considerable demands of all the main players in Northern Ireland but not least of Unionists. If the political future the Belfast Agreement imagines will take real shape then Unionists must substantially revise and perhaps completely abandon the way they relate to the Irish Republic. This represents an extremely difficult ideological enterprise.

Since the early days of partition, Unionists have acted almost as if the Irish Republic simply does not exist. The Unionists' cultural field of vision usually 
excludes the remainder of the island; instead, they locate themselves within an "imagined community" that shares boundaries with the United Kingdom. For the last century most of the Unionist community has understood itself to be "British." Over the period of the present conflict these feelings of identification with the other island have become even keener.

Since the early 1970s a complex set of social processes has drawn many Unionists more fully into the United Kingdom's wider cultural and political life. The current generation of Unionists has rather greater knowledge and experience of the other regions of the British state than their predecessors did. The organization of work in Northern Ireland means that many Unionists regularly interact with colleagues in Cardiff, Edinburgh, London and elsewhere. They routinely fly to destinations "across the water" for business meetings and recreational pursuits. The mainstream British media's penetration of the region has made Unionists more familiar than ever before with contemporary UK cultural and political debates.

Their cultural location has caused most Unionists to simply never give the Irish Republic a great deal of thought. Northern Unionists have remarkably little knowledge of the matters and figures that animate public life south of the border. When Unionists have actually brought themselves to think about southern Irish society, they have been unremittingly hostile. The Unionist construction of the Irish Republic has been relentlessly dystopian. In Unionist minds, the course the 26 counties have followed since partition has infringed those ideals of liberalism and pluralism to which they often proclaim devotion. The architects of southern Irish society are viewed as assuming there's only one "people" united in their commitment to a common ethnoreligious heritage. Unionists claim the Catholic Church has exerted an authoritarian and baleful influence over the social life of the 26 counties. Each incident viewed as an abuse of clerical power provides Unionists with further damning evidence that the Irish Republic is a sectarian state.

$\mathrm{U}$ nionists have often argued that the moral orthodoxy claimed by the Republic of Ireland has undermined personal freedom of expression, that individuals who have resisted conservative Catholicism feel shunted to the margins of political and cultural life. According to Unionists, the stifling moral authoritarianism that shrouds the Irish Republic further discriminates against social collectivities with cultural traits that differ from the main ethnoreligious tradition. The Unionist reading of history insists that Protestants living in the 26 counties have fared badly since partition. The decline in the size of the Protestant community south of the border offers many Unionists compelling evidence of the cultural intolerance they associate with the Irish Republic.

In the eyes of Unionists, the social order of the Irish Republic has been fashioned in the image of a people assumed to be not only exclusively Catholic but entirely Gaelic as well. The course of the 26 counties since partition is viewed as one of cultural introspection. Irish Republic leaders are held to have rejected the opportunity to move within the UK's broader cultural environment and beyond, and instead to have moved only within the restricted intellectual orbit of "small town hibernianism." For Unionists, the Irish Republic's essential 
parochialism has preserved public life south of the border in the stunted form of a "Gaelic cultural tyranny."

Unionism has long assumed that the Irish Republic's cultural underdevelopment mirrors its economic backwardness. In the decades that followed partition, a substantial gap opened between the two economies on the island. By the time the troubles erupted in the late 1960s living standards in Northern Ireland had moved substantially beyond those of the Irish Republic. Unionists have always highlighted the economic misfortunes that have periodically overtaken the 26 counties. Unionists regularly dismiss southern Ireland as merely a "potato republic" whose economic retardation finds keen expression in the desperate condition of its public roads.

In the past, the orthodox Unionist conception of the Irish Republic could be said at least to have had a grain of truth. Were we to cast our minds back to the late 1980s, for instance, the argument that southern Ireland constituted an economic casualty would seem rather persuasive. The events since then, however, have left Unionist readings of the Irish Republic looking distinctly tendentious. Over the last decade, southern Irish society has undergone a remarkable process of change. A series of sexual abuse scandals has both heralded and accelerated the seemingly terminal decline of the Catholic Church. Legislation has been introduced that promises to underwrite a range of indispensable personal freedoms. The success of artists in an international range of fields indicates how fashionable Irishness has recently become. Perhaps the most remarkable changes, however, have been those in the realm of economics. Since the mid-1990s, the 26 counties have registered economic growth rates that are the envy of other Western European states. The apparent economic miracle the Irish Republic now enjoys has, of course, inspired the ubiquitous and increasingly tiresome metaphor of the "Celtic Tiger."

The Irish Republic's recent transformation has fatally undermined many of the central arguments of Unionist orthodoxy. The view of southern Ireland as a materially retarded cultural backwater would seem simply perverse to anyone who has strayed through Cork, Dublin or Galway over the last few years. The speed and scale of change within the 26 counties have thus far proved insufficient, however, to persuade Unionists to re-evaluate the Irish Republic. In their recent writings, Unionist intellectuals still portray a Republic of Ireland that bears little resemblance to the reality south of the border. Unionist opinion forumulators still emphasize clerical abuses in the past as evidence of pervasive sectarianism in the present. Unionist politicians still portray the Irish Republic as a "third world" country by making juvenile references to the potholes that remain in some southern Irish roads.

The marked reluctance of Unionists to acknowledge the Irish Republic's advances suggests the scale of difficulties the peace process faces. The political settlement that is currently being put into place seeks to reconcile the two principal ideological traditions on the island. Most of those who lent their names to the Belfast Agreement envisaged a future in which the Unionist community would adopt a more mature and cooperative stance toward the Irish Republic. Some may even have regarded the deal as the first step toward Unionists regarding themselves as Irish men and women. So far, however, the Unionist community has been neither willing nor able to make the leaps of political faith 
the Belfast Agreement demands. In more specific terms, the Unionists seem unwilling to amend their vision of the Irish Republic in ways essential to a political settlement.

$\mathrm{O}$ f course, it would be premature to suggest that the Belfast Agreement is doomed to failure. The changes imagined by those who struck the deal are fundamental and it will take a long time for any or all of them to come to fruition. This is no less true of the Agreement's North-South dimension than it is of the other constituent elements. Even if Unionists are overtly hostile to the Irish Republic today, that does not of course mean they will always remain so. The prospects that Unionists may soon negotiate a more civil and productive relationship with those with whom they share the island will hinge upon several considerations.

First, whether Unionists can look south rather than east depends upon the institutions established under the Belfast Agreement. Several bodies have been created to consider matters of concern for people on both sides of the Irish border but they remain limited both in number and in authority. Indeed, Nationalist representatives have been dismayed that the Agreement's NorthSouth dimension has not been given greater substance. But while cross-border institutions now seem fairly insubstantial, this will not likely remain so for long. If the fragile peace process survives, the scale of authority available to bodies with jurisdiction over the island as a whole will grow considerably.

The gradual strengthening of such institutions may alter the disposition of the Unionist community. In the short term, influential Unionist figures will necessarily pay greater attention to the Irish Republic than has historically been the case. Unionist politicians, civil servants and business people will be compelled to interact with bodies that have one leg in the 26 counties. As the leaders of Unionist opinion cultivate closer ties with the Irish Republic, the wider Unionist community will likely follow suit.

If the powers at the disposal of North-South bodies were to expand as anticipated more Unionists would be drawn inevitably into the island's wider public life. Decisions affecting their lives would increasingly be made south of the border; this would likely nurture Unionist interest in the Irish Republic's cultural and political affairs. It would then become routine for Unionists active within civil society - including trade unionists, professionals, and community representatives - to travel to Dublin and elsewhere to influence the course of public policy. These heightened connections with the Irish Republic might alter Unionist cultural and political inclinations. As their associations with southern Irish society grow, Unionists may stop regarding the rest of the island as irretrievably alien. The Unionist community might even consider a united Ireland as a place they might be willing to consider home.

$\mathrm{T}$ he second process relates closely to the first. At present the island of Ireland contains two relatively discrete economies. The trade and investment that cross the Irish border remain remarkably meager. This will not likely continue for long. Over the last decade business people on both sides of the border have realized the possibilities of economic integration. Thus, the two economies will 
likely become increasingly entangled. Given the recent emergence of the Celtic Tiger, the Irish Republic will likely have greater significance for the economic fortunes of Northern Ireland than vice versa.

The process of economic integration can perhaps transform the Unionists' cultural field of reference. Gradually dissolving the boundaries between the two Irish economies would draw important swathes of the Unionist community into networks that encompass the entire island. Unionist business men and women who used to travel regularly to various locations across the water might begin venturing as routinely to the likes of Athlone or Roscommon. Civil servants charged with economic development who have Unionist backgrounds might find themselves making rather fewer calls to Great Britain or the United States, and more to the Irish Republic. Trade unionists operating in plants established in Unionist neighborhoods but financed with southern Irish capital might find it increasingly necessary to follow the affairs of the Dublin parliament.

The growing tide of trade and investment flowing across the Irish border will likely transform the Unionist outlook. Dismantling the barriers between the two Irish economies will likely initiate processes that will enable Unionists to better understand those with whom they share the island. As these cultural associations accumulate, the Unionist community might develop a more amicable relationship with the Irish Republic. Were Unionists to cease regarding other Irish men and women as strangers, then the political possibilities would widen considerably. While a united Ireland would of course be rather less than inevitable it would also be rather less unlikely.

The third and final consideration focuses on the conduct of perhaps the most important player in the Northern Ireland problem. If Unionists are to genuinely redefine their troubled relationship with Irish Nationalists, much will depend on the British state. For most of the last century, Westminster and Whitehall have been profoundly ambivalent toward Northern Ireland. While the British political establishment has often wished to be rid of the region, it has nevertheless been unable to imagine the conditions for doing so. London's ambivalence has been severely debilitating for the Unionist community. The realization that the British state wishes to abandon Northern Ireland has inevitably fuelled the paranoia that corrupts the Unionist political imagination. The reluctance of Westminster to act upon this political ambition, however, has prompted among Unionists those puerile forms of intransigence that have left them all but without friends or influence.

The future of Unionism and of the entire peace process will, therefore, hinge largely on the future conduct of the British state. For there to be real political progress in Northern Ireland in the difficult years to come the London political establishment will have to abandon its ambivalence. In simple terms, the British state will finally have to come clean. To avoid the dreadful stalemate that has plagued the recent past, politicians and others in London will have to state openly and consistently that the British state wants to leave Northern Ireland and that it will create the conditions to do so. Adopting a more honest stance would transform the public debate in the six counties. Coming to grips with London's abandonment of Northern Ireland will make Unionists understand that though they have a future, Unionism does not. Political necessity will dictate that Unionists move beyond past assumptions towards a better political future. The 
Unionist community might even relinquish their unrequited devotion to the other island so as to imagine more amicable and equitable relations with those on the island they happen to share.

We cannot, of course, predetermine Northern Ireland's future. The route the $\checkmark$ region will follow in the next few years will depend on the actions taken - or not taken - by real people. While Northern Ireland's political destiny remains undecided, some potential outcomes seem more likely than others. The political affairs of the last 15 years have nudged the six counties in a particular direction. The undertow of the current peace process is evidently drawing the people of Northern Ireland away from Great Britain and toward the Irish Republic. Having a genuine political settlement in the region will require substantial changes in Unionist outlook and practice. At some stage Unionists must revise outdated beliefs so as to develop a more rewarding relationship with their fellow Irish men and women. As with most things, there is no time quite like the present.

\section{RECOMMENDED READINGS}

Coulter, Colin. 2000. "“A Miserable Failure of a State': Unionist Intellectuals and the Irish Republic." in Ray Ryan (ed.), Writing in the Republic. Dublin: Gill \& Macmillan.

Kennedy, Dennis. 1988. The Widening Gulf. Belfast: Blackstaff.

McGarry, John \& Brendan O'Leary. 1995. Explaining Northern Ireland. Oxford: Blackwell.

Ruane, Joseph \& Jennifer Todd. 1996. The Dynamics of Conflict in Northern Ireland. Cambridge:

Cambridge University Press.

Colin Coulter is a lecturer in the Sociology Department at the National University of Ireland, Maynooth. He is the author of Contemporary Northern Irish Society. Correspondence: Department of Sociology, National University of Ireland, Maynooth, County Kildare, Ireland. E-mail: colin.coulter@may.ie 